\title{
OPEC's Benefit for the Member Countries
}

\author{
Jamola Khusanjanova \\ Institute for Development and Human Security \\ \#802 IEB, Ewha Womans University \\ 11-1 Daehyun-dong, Seodaemun-gu, (102-750) Seoul, Korea \\ Tel: +82-10-5706-6181 E-mail: jamola@ewhain.net
}

Received: January 30, $2011 \quad$ Accepted: March 3, $2011 \quad$ doi:10.5430/rwe.v2n1p14

This research was supported by WCU (World Class University) program through the National Research Foundation of Korea funded by the Ministry of Education, Science and Technology (Grant Number: R32-20077).

\begin{abstract}
The Organisation of Petroleum Exporting Countries (OPEC) is a permanent inter - governmental organisation composed of member states whose economies mostly rely on revenues from oil export. The OPEC's twelve members work together to coordinate the overall oil price in the world market. So far, there have been numerous studies on OPEC's influence on the world petroleum market. Current study mainly looks at the role of OPEC in development of the member countries. Investigates what kind of benefits does the member countries get from being member of the Organisation of Petroleum Exporting Countries and its influence on the economic development of the member countries.
\end{abstract}

Keywords: OPEC, Member country, Benefit, Economic growth

\section{Introduction}

Energy resources due to their specific nature are key product and strategic commodity in today's international society. Industry worldwide is dependent on the resources for survival and their cost will always affect the price of the finished product, thereby controlling energy supply is a powerful tool in today's international market.

The member states of Organisation of Petroleum Exporting Countries had an early understanding of this new international economic system. Furthermore, the member states realise their potential to shift the balance of power from the West. OPEC is a permanent, intergovernmental Organization, created at the Baghdad Conference on September 10-14, 1960, by Iran, Iraq, Kuwait, Saudi Arabia and Venezuela. The five Founding Members were later joined by nine other Members: Qatar (1961); Indonesia (1962) - suspended its membership from January 2009; Socialist People's Libyan Arab Jamahiriya (1962); United Arab Emirates (1967); Algeria (1969); Nigeria (1971); Ecuador (1973) suspended its membership from December 1992-October 2007; Angola (2007) and Gabon (1975-1994).

OPEC is one of the oldest organizations founded by developing countries, having survived half a century since its establishment. According to data from official web page of OPEC, in 2009, this organization possessed $79.3 \%$ of global proven crude oil reserves and was responsible for $60.3 \%$ of the world's crude oil exports. (www.opec.org)

This organization has been known as an international organization rather than a regional or intergovernmental one. In fact, OPEC's decisions about levels of production have a global effect, as international oil markets are inter-related and oil can be transferred from one market to another. Moreover, by building more and more sophisticated refineries, crude oil is becoming more like a homogenous commodity, so that the supply and demand of a specific type of a crude in one corner of the global oil market will affect the fundamentals of other crudes in another part of the global oil market. Moreover, OPEC can easily affect on oil price and its supply.

Nowadays in case of OPEC scholars mainly look at the oil production its reserves, price monopoly and impact of OPEC's quotas on world oil market (see Loderer 1985, Griffin and Xiong 1997,); they test OPEC's behavior and its impact on the oil prices as well as market (see James 1999, Noguera J. and Pecchecnino R. 2006) and its role in providing sustainable development. However, there are a few studies that test whether there is any benefit for the oil producing countries to be the member of organization of petroleum exporting countries and what are they.

As Noguera J. and Pecchecnino R. (2006) has emphasis in their studies there two economic goals of being member of OPEC. One is macroeconomic - reaching low oil market volatility, and second one - microeconomic is to promote 
economic development of the country. Since oil revenues are vital for the economic development of the OPEC nations, they aim to bring stability and harmony to the oil market by adjusting their oil output to help ensure a balance between supply and demand. Also some scholars as Morrison (2004) argues that because of the high level of oil dependence, the oil sector must perform well in these nations both to maintain current and ensure future living standards. On the other hand, oil sector and overall economic productivity in the OPEC economies has declined, and today less rather than more is being produced with the same resources.

Taking in to account that OPEC is one of international organisation with long history, permanent members and huge impact on world energy supply and market. Also, considering fact that completely all members of OPEC are developing countries it would be interesting to know how OPEC is beneficial for the member countries despite the quotas for oil producing. Taking in to account this circumstance in the paper I also want to see what kind of and in which spheres the member countries get benefits.

The paper is organized as following: at first part, I am going to see whether OPEC influence on member countries' economic growth. In the next part will be seen whether the member countries have made benefit by oil exporting, despite the existing quotas on oil production. Then I will test hypothesis posted as OPEC promote sustainable development for member countries, as well as for other developing countries. The methodology used in this paper are in-depth interviews with representative of well knowing oil producing companies and content analysis of official documents from the OPEC and affiliated organisations' web pages related books and academic articles as well as other findings.

\section{OPEC Influence on Economic Growth of the Member Countries}

OPEC is commonly described as Cartel, which is intergovernmental organization. However, according to the statue of OPEC, it define itself as an international organization with aim to influence and maintain the price of oil through the control of production levels and to generate revenue, which goes towards meeting the development needs of its members.

However, OPEC's influence on the oil markets has significantly diminished compared to the 1970's OPEC is still the key player of world energy market. Nowadays the organisation supplies about $60 \%$ of world oil output and more than $75 \%$ of world petroleum reserves are located within OPEC nations; and OPEC policy instruments have consistently been confined to fiscal and pricing measures (Logman 1982).

$<$ Figure 1about here $>$

Former Acting OPEC Secretary-General, Fadhil Al-Chalabi has emphasized that OPEC's objective is to co-ordinate and unify petroleum policies among the member countries, in order to secure fair and stable prices for petroleum producers, member countries, as well as, efficient economic growth for the member states, and regular supply of petroleum to consuming nations (World oil outlook 2010).

Many scholars argue that OPEC has evolved over the years and has become a market phenomenon. Since the early 1970s, a significant degree of "re-integration" has been achieved in the world oil industry, between OPEC minor and major member countries (Yang 2004), member countries and the biggest oil-producing companies. Moreover, OPEC influence on the growth and promote economic growth of its member countries through fair return of capital, that is mentioned in OPEC statue, to those member countries who investing in their industries that would lead to economic development of the member countries (OPEC statue article 1-2).

OPEC's influence on the economy of the member countries is great, since most member countries derive more than $80 \%$ of their foreign-exchange earnings, as well as huge share of GDP, from oil and gas exports. In turn, receipts from the oil and gas sector account for at least $70 \%$ of government revenue. (Appendix Table 1 and 2)

\section{$<$ Tablelabout here $>$}

Unsurprisingly, the performance of the member countries' national economies is closely linked to the fortunes of the domestic oil and gas sector. Investment in oil and gas determines the potential for the sector to provide either leverage financial resources for economy-wide development or diverse it through reinvesting. Judged by a number of measures, OPEC member countries have made varying degrees of economic and social progress over the past 30 years. Perhaps less debatable and doubtful is the idea that it is now time to review the existing sources of development finance and the modalities for it in OPEC member countries.

As I have already mentioned OPEC member countries is divided in to two minor and major countries. Scholars made this diversification according to the hydrocarbons reserve and number of population. Most minor OPEC countries are those that have large populations and smaller oil reserves (such as Algeria, Indonesia and Nigeria). Major OPEC countries are those countries that have larger hydrocarbons reserves and smaller population. 
I assume that for describing economic influence of OPEC on the member countries growth I should narrow down my observation to one country. However, Indonesia nowadays is a former member it would be appropriate example to demonstrate economic influence of OPEC even on minor country. While Indonesia was member of OPEC, since 1962, it has a relatively diverse its economy by reinvesting, as it was already mentioned, from the oil industry toward other sectors. Despite the fact that, Indonesia was not well develop country, even within the OPEC countries, with a large external debt. Indonesia was able to divers it economy from oil based economy to manufacture. As evidence we can observe that in 2005 Indonesia became a net oil importer for the first time in decades (EIA, 2004) - this had implications for its membership of OPEC.

Therefore nowadays Indonesia is not heavily dependents on oil export. That diversification was done with help of the reinvesting the income from the revenues obtained by Indonesia within OPEC (table 2). According the data from World Bank for 2005, the services sector in Indonesia is the largest sector of economy, nowadays, and accounts for $45.3 \%$ of GDP (2005). This is followed by industry (40.7\%) and agriculture (14.0\%). However, agriculture employs more people than other sectors, accounting for $44.3 \%$ of the 95 million-strong workforce. The service sector of economy is followed by the services sector (36.9\%) and industry (18.8\%).Major industries include petroleum and natural gas, textiles, apparel, and mining however, the share of petroleum industry in Indonesian GDP has decreased over last years. (Indonesia in a Glance 2006).

$<$ Table 2 about here $>$

The UAE, Saudi Arabia are another examples of OPEC major countries that have larger oil reserve and smaller population and that countries slightly diversify their economy, moving increasingly towards services (tourism, banking, re-exports, and information technology) (EIA, 2009). Kuwait and the UAE are the only two Gulf States, which are relatively independent from oil prices because of the structure of their finances and economy; the other Gulf States will continue to need higher oil prices to fund their increased levels of expenditure (Barnett J. 2008 citied from Kohl, 2002).

Additionally, as it mentioned in the human development report by UNDP (2003) Saudi Arabia is the world's largest crude oil producer, a leader in OPEC's production quota decisions and certainly the most active member of OPEC. However, Saudi Arabia has diverse its economy oil dependence continues to dominate the in Saudi economy (appendix Table 1). Income in Saudi Arabia remains low from non-oil sources. (Inter-American Development Bank Office of the Chief Economist Working Paper 312) As a result, the government's budget is highly vulnerable to oil price volatility.

Improving OPEC member countries' economies is absolutely essential for OPEC, since it is one of the aims of organisation. Thus, it is significant for the organisation to continue and increase investment in their member countries' economy in the coming years. Oil export revenues dominate the economies of these countries. Although this revenue will continue to increase in the future, there is a point where oil will run out, and all the money that is generated by oil will disappear with it. That is why these investments need to be implemented immediately. Investments made into oil and gas projects that stretch beyond maintenance and production expansion would significantly benefit these natural resource heavy economies. Of equal importance is investment in social capital; education, transportation, telecommunications, healthcare, etc and the investments toward economic diversification. If these investments are made while oil revenues are steadily increasing, OPEC member countries will benefit socially and economically in the future.

$<$ Figure 2 about here $>$

Nonetheless, as it is emphasized in the statue OPEC, as an international organisation has proved to have a very strong economic character. It has shown this by targeting the development of its member states as a goal to achieving the highest GDP growth possible.

\section{OPEC's Benefits to the Member Countries}

OPEC members benefits from it in several ways. Mainly they could be divided in to two as follow: economical that we have already seen in previous part; and political. In this part of my paper, I am going to look at other than economical benefits of being OPEC member. Additionally, in this part of my paper I would like to examine whether OPEC member countries make large benefit by exporting oil within OPEC despite the existing quotas on oil producing for the member countries.

Among all international trade organisations, OPEC has proved to be a good example of an alternative international political economy with an undisputed amount of bargaining power and one of the few powerful organisations not controlled by the West (Farhan Al-Farhan 2003). This gathering brings great benefits in both economic and political sense for oil exporting countries. 
One of the benefits for the member countries can be identified regarding to the primary purpose of OPEC, which is to secure its member countries' fair shares of the value of their oil resources, for the purpose of accelerating economic development and improving the welfare of people of the member countries (Iz Osayimwese 1999). Another non-economical benefit for the members of the organisation, is that OPEC protects its member countries interest, within the oil market and the global arena. (BB Alizadeh MEES 9 febrary, 7 December 2009) Also the fact the organization provide and willing to increase its development assistance to the minor member countries is another advantage; since this will lead to divers economy, reduce external debts create new work places, reduce poverty and malnutrition.

Despite those benefits, it is also important for the member countries that the organization provides opportunity to influence on Western countries as most of them depends on the OPEC oil, as well as paying key role in the global oil market/ industry. This also includes the murky international politics synonymous with the oil industry. As we know OPEC emerge in time when the cold war has just end, and international attention was focused on the tense situation between the Eastern Block and the Western powers.

AL-Otaiba's (former Minister of Petroleum and Mineral Resources of the United Arab Emirates under the Presidency of H.H Sheikh Zayed bin Sultan al Nahayn) argument that he provides can be interpreted as OPEC countries had the opportunity to be considered as a serious power within the new international system and should use that rationally in order to achieve their own countries goals. The classical definition of power is "... the ability to get people to do what you want them to do" (Krasner p.3). The power of OPEC can be viewed in relation to the rational aspect and absolute role when it used the right strategies and policies to achieve its member countries' goals. Another way that the union is beneficial for the member countries is that the countries which located in the East are secure in terms of wars and other conflicts (OPEC working paper 2003) but I have doubt on this statement (the two Iraq wars). The benefit from OPEC to non-OPEC counties is that OPEC focuses its activities on ensuring order and stability in the international oil market with reasonable prices.

The declaration reiterated that OPEC would go ahead in its efforts to accelerate economic development in the developing countries through its aid programs; The International OPEC Development Fund and the International Fund for Agricultural Development. It is urged the industrial countries to contribute positively to these efforts and to work towards the reduction of debts of the developing countries.

Regarding to the more real benefits gained directly from oil export, OPEC in its long term strategy, has emphasized that

...unstable prices cause difficulties in the interpretation of signals sent by market. It makes no difference whether such signals are indicative of the market's structural change or is resulting from a temporary phenomenon. Therefore, it is difficult to support long-term market stability only by one supplier, if prices remain unstable. (OPEC long-term strategy:4)

Thus, I think it can be argued that being OPEC member is beneficial as the member countries by establishing and joining to OPEC make themselves free from dealing with this kind of issues furthermore get larger economical benefits by playing together. Besides, OPEC in its long term strategy, has also stipulated ...

...when the market is tight, very high prices may influence economic growth, especially in developing countries, threatening future demand growth for oil. Meanwhile, very low prices could also limit the trend of economic development and social welfare of OPEC member countries...Thus, avoidance of a market faced with excess of supply or shortage of supply is necessary. The presence of more members in OPEC would increase the organization's ability to stabilize the market. (OPEC long-term strategy:7)

As it was already mentioned, OPEC countries manly drive their main revenues to the GDP from oil export (OPEC annual reports 2000-2009). I think it is obvious that the OPEC provide economic growth to the member countries thought the revenues from oil trade. Thus, it is significant to underline role of OPEC in oil market and pricing. Moreover, understand how the member countries are making large benefit from oil export despite the existing quotas on oil production settled by OPEC.

The aim of OPEC is to provide stabile prices on oil for the member countries by controlling the prices through quotas. OPEC provides equilibrium and sustainability between such market phenomena as consumers demand on crude oil and supply of the producers, by using the tool of quotas on oil producing. OPEC implement the main rule of market is that is, when the there is larger supply of goods and services the prices go down and when there is larger demand the prices go up, within its member countries by using the quotas. That helps it to control the prices on oil. As, the member countries of OPEC are the larger producers of oil, its decisions regarding the quotas, directly affect on the world prices on oil. Thus, it can be argued that the quotas are providing to the OPEC countries opportunity to make larger benefits. Despite 
the fact that it is commonly argued, that the quotas are the barriers for the member countries to make larger benefit. It is obvious that the quotas are the main tool that let to maintain preferable by the suppliers, OPEC countries, prices on oil in the market and keep the prices beneficial for both consumers and suppliers. Furthermore, according to the OPEC statue following to the quotas in oil production volume is not mandatory.

\section{OPEC as a Promoter of Sustainable Development}

In this part of the paper I am going to see the OPEC's activity toward promoting sustainable development for the member countries, as well as for other developing countries. OPECs aid organisations were noted as good examples to the developing countries in the early 1970s. OPEC member states, acting in partnership, decided in the 1970s to join forces to achieve greater effectiveness and relevance in the field of development assistance delivery. The aim from the idea was to have greater impact and to better manage official aid resources, which were increasing in both volume and significance.

In 1975, OPEC also called industrialised developing countries to come together to solve the problems poor countries are facing and to look for ways of establishing a better economic system by allowing increased trade and exchange of knowledge (OPEC review vol. 3.2 1979). OPEC established the OPEC Fund for International Development (OFID) in January 1976 (originally called the 'OPEC Special Fund') to promote cooperation between OPEC Member Countries and other developing states. In particular, OFID aims to help poorer, low-income non-OPEC 15 countries in their pursuit of social and economic advancement. OFID is active in many regions, including Africa, Asia, Europe and Latin America. It has supported a wide range of projects, from providing clean water and energy to remote communities, to building schools, hospitals and roads and developing industries, farming and trade opportunities. Since its establishment, it has made commitments totaling nearly US $\$ 10.1$ billion, two-thirds of which have already been disbursed.

The Third Summit of OPEC Heads of State and Government in 2007 reaffirmed OPEC's commitment to energy for sustainable development. The concluding Riyadh Declaration stated that energy was essential for poverty eradication, sustainable development and the achievement of the Millennium Development Goals (OPEC annual report 2007). It associated Member Countries with all global efforts aimed at bridging the development gap and making energy accessible to the world's poor.

Over the last three decades, some experts have highlighted the vital importance that OPEC has played in the socio-economic development and the huge growth of the member states.

OPEC participates in development financing at two levels. First, individual member countries finance domestic capital investment from a combination of domestic savings and external borrowing and aid. Second, as a group, OPEC countries provide concessional finance for development projects in non-OPEC developing countries (Note1). OPEC's development assistance is provided through the OPEC Fund for International Development, established in 1976 as a multilateral agency with a mandate that combines some elements of the activities of both the World Bank and the IMF.

The financing of oil and gas projects is a paradigm for development financing in the member countries' economies. OPEC countries are still far from achieving the goal of transforming their enormous hydrocarbon wealth into human and physical capital for sustainable economic development. To achieve their goal, member countries need to invest massively in oil and gas projects, beyond just maintaining and expanding production capacity. Practically all member countries are financially strained. All of them face, in varying degrees, undue geopolitical risks that limit their access to external financial resources, under the existing international financial infrastructure. Moreover, all OPEC countries have experienced the "Dutch disease" at some time in the past, and one member country suffers an extreme form of the disease (Note 2).This being a "regional" epidemic, the Dutch disease deserves appropriate response from the custodians of international financial health.

Since 1971 OPEC member states, acting individually and concerned by the difficult economic circumstances of neighboring countries, had provided assistance to their neighbors (Ibrahim F.I. Shihata 1982 p 47-59). At the multilateral level, the objective has been to cooperate and coordinate to make the total aid effort more effective. OPEC has successfully managed, over the years, to establish a set of international aid bodies. These are:

The Arab Authority for Agricultural Investment and Development (AAAID) is an investment organisation consisting of 15 Arab states aimed at improving food security in Arab countries. Its objective is to develop agricultural resources in the member states by investing in all forms of agricultural production and related activities. Particular areas of involvement include: land reclamation; plant, animal and fish production; pastures and forestry creation; the transportation, storage, marketing, processing and exporting of agricultural produce; and, all inputs necessary for agricultural production. 
Arab Gulf Program for United Nations Development Organizations (AGFund) Seven Arab Gulf countries (Bahrain, Iraq, Kuwait, Oman, Qatar, Saudi Arabia and the United Arab Emirates) contribute to the resources of the AGFund, an organisation that provides grant assistance to UN agencies and Arab NGOs in support of humanitarian projects. The type of projects supported by the AGFund is in the fields of health, nutrition, water and sanitation, education, the disabled and the environment. The main beneficiaries of this fund are mothers and children.

Arab Monetary Fund (AMF) was established by Arab countries with the objectives of laying the monetary foundations of Arab economic integration, accelerating the process of economic development in all Arab nations, and promoting trade amongst them. The main activity of the AMF is the provision of loans in support of economic adjustment programs.

Arab Fund for Economic and Social Development (Arab Fund) finances projects for economic and social development in Arab countries. With a membership comprising all 22 members of the League of Arab States, it extends concessional loans to governments as well as to public and private organisations. Preference is given to projects that are of vital importance to the Arab world and to joint ventures involving Arab cooperation

Arab Trade Financing Program (ATFP) is a specialised financial institution launched by the Arab Monetary Fund in 1989. Its objective is to develop and promote trade between Arab countries and enhance the competitive ability of Arab exporters. The ATFP functions as an autonomous body and operates through designated national agencies.

Arab Bank for Economic Development in Africa (BADEA) seeks to promote economic, financial, and technical cooperation between African and Arab countries. Funded by Arab governments, it finances economic development in African countries, stimulates the contribution of Arab capital to African development, and provides technical assistance.

Islamic Development Bank (ISDB) is to foster economic development and social progress in member countries and in Muslim communities in accordance with the principles of Islamic Shariah. Its membership consists of 52 countries, which are also members of the Organization of the Islamic Conference. IsDB has the authority to extend financing and raise funds in many ways and to establish special funds for specific purposes.

Providing assistance to these countries to diversify their economy, technology transfer, and capacity building can be cited as being among these commitments from the figure bellow we can see how the founds are divided between the sectors. That the main share, are transportation, energy, agriculture and agro - industry education, water supply, and other. In providing assistance it agricultural and agro - industrial sectors OPEC cooperate with IFAD, together they provide assistance mainly to the southern African and eastern countries(www.ifad.org/pub/index.htm).

$<$ Figure 3 about here $>$

OPEC's efforts to establish cooperation with the World Trade Organization (WTO) is yet another example that can be mentioned in this regard. Based on OPEC's long term strategy, implementing an active role by OPEC in commerce has great significance, especially as far as developing countries are concerned. OPEC member countries continue to consolidate and promote economic growth and social development using the relative advantage resulting from their natural resources. The collective interests of member countries lie in pursuing such policies. Thus, any other country becoming an OPEC member can also benefit from the outcomes and the effects of the organization's policies.

\section{Conclusion}

OPEC's oil has been a vital source of energy for the world during the last half of century, and will continue to be so throughout the 21 st century. The economic performance in all OPEC countries, except Indonesia (former member), largely mirrors the behavior of the oil and gas sector. Oil price volatility often translated instantaneously into sharp fluctuations in foreign-exchange earnings and government revenues, with serious implications for macroeconomic management. Thus, the financing of oil and gas projects is a paradigm for development financing in the member countries' economies.

Concluding the findings it can be argued that the Organisation of Petroleum Exporting Countries is economically beneficial for the member countries. Since OPEC has influence on member countries' economic growth and development. That we could observe in case of Indonesia. Moreover, despite the existing quotas on oil production, the member countries make benefit by oil exporting. OPEC influence and maintain the prices of oil by controlling the volume of oil production and generate revenue. Those revenues later go to development the member countries economy and to other fund that help to OPEC members and other countries in their development. Additionally by the quotas organization is able to influence on the prices in world oil market; and from the presented findings it was obvious that exporting countries do benefit from the quotas and being member of OPEC. 
Through foundations that founded by the member countries and the OFID OPEC promote sustainable development for member countries, and for other developing countries. OPEC is one of the main donors of IFAD that also facilitate OPEC activities in agricultural sectors of member and developing countries.

However, despite big revenues from oil exporting, OPEC countries are still far from achieving the goal of transforming their enormous hydrocarbon wealth into human and physical capital for sustainable economic development. To achieve their goal, member countries need to invest massively not only in oil and gas projects, beyond just maintaining and expanding production capacity, but also in economical diversification. Practically all member countries are financially strained. All of them face, in varying degrees, undue geopolitical risks that limit their access to external financial resources, under the existing international financial infrastructure.

For further research I think it would be interesting to see whether the Indonesian experience can be implemented for other member countries, especially for minor OPEC member countries. And to test is within OPEC any key payer country which, influence on decision making process regarding quotas and funds distribution.

\section{References}

Amuzegar, J., Tauris B., (1999) Managing the Oil Wealth: OPEC's Windfall and Pitfalls. London.

Annual Energy Outlooks 2005 - 2010

Barnett, J., (2008) The Worst of Friends: OPEC and G-77 in the Climate Regime. Global Environmental Politics - Volume 8, Number 4.

Danielsen, A., (1982) Evolution of OPEC. p 126 Harcourt Brace Jovanovich Publisher, (Chapter 3).

Deaton A., (1989) "Saving in Developing Countries: Theory and Review" Proceedings of World Bank Annual Conference on Development Economics, Washington, DC.

Farhan Al-Farhan (2003) The Saudi Arabian Experience and what is needed in the 21st century OPEC Policies and the Economic Development of Member States, OPEC.

Humphries, M., (1995) Competitive environment of oil and gas financing, Energy Policy, Volume. 23, Number 11, pp. 991-1000.

Hunter, Sh., (1984) OPEC and the Third World: The Politics of Aid, Indiana University Press, Bloomington, (Chapter 4, 6).

Ibrahim F.I. Shihata (1979) The other face of OPEC: financial assistance to the Third World Longman.

Iz Osayimwese (1999) OPEC:The quest for alternative financing for development, OPEC, Number 2.

Inter-American Development Bank Working Paper 312 (1995) "Testing the hypothesis of collusive behavior among OPEC members"

Inter -American Development Bank's reports 1995-2009

Knott, D., (1995) OPEC States Seeking More Foreign Investment in Petroleum Sectors," Oil \& Gas Journal, July 29.

James, R. (1999) New Cohesion in OPEC's Cartel? Pricing and Politics Middle East Review of International Affairs Volume 3, Number 2.

Noia, P., (1998) Where Will Oil Industry Financing Come From?, Oil \& Gas Journal, May 1.

Nogueraa, J., Rowena A. Pecchecninob, (2007) OPEC and the international oil market: Can a cartel fuel the engine of economic development? International Journal of Industrial Organization p 187-199.

OPEC Fund for International Development, (2000-2009) Annual Reports, Vienna, Austria.

OPEC review (1979) Food production developing countries major contrast and possible solutions, Volume 3.

OPEC Secretariat, (2010) OPEC long-term strategy: $p$ 4,7. Vienna, Austria

Saud Al-Ammari (2010) Saudi Arabia and the Onassis arbitration - A commentary World Energy Law Bus Volume 3 Number 3: 257-259 first published online September 24, 2010 doi:10.1093/jwelb/jwq008, http://dxdio.org/10.1093/jwelb/jwq008

Morrison, K., (2004) Pressures at home prey on the minds of OPEC ministers. Financial Times Thursday, July 8.

Ibragim (1982) p 47-59 
UNDP Human Development Report, 2003

Ukpanah, E. (2002) OPEC as a Cartel: Can U.S. Antitrust Laws Be Applied Extraterritorially? University of Dundee.

Research paper prepared by OPEC public relations department (1979) Evaluation of OPEC aid to LDC's OPEC review Volume 3 Number 2 doi: 10.1111/j.1468-0076.1979.tb00069.x http://dx.doi.org/10.1111/j.1468-0076.1979.tb00069.x

Rueda, A., (200) Price-fixing at the pump: Is the OPEC oil conspiracy beyond the reach of the Sherman Act? Houston Journal of International Law p. 9, Fall.

Yang, A., (2002) OPEC: An Analysis Of Future Economies And Aid Lusignan

Yergin, D., (1997) The Prize: The Epic Quest for Oil, Money and Power Pocket Books p 523.

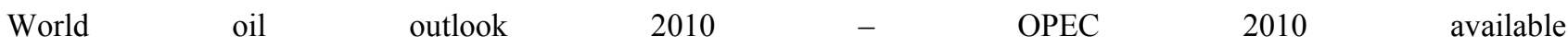
onlinehttp://www.opec.org/opec_web/static_files_project/media/downloads/publications/WOO_2010.pdf (last visit 2011.02.22)

World Bank (2006) Indonesia in a glance World Bank

\section{Web sources}

http://www.opec.org/Publications/GI/Gen/info.pdf

http://www.tradingeconomics.com/Economics/GDP-Per-Capita.aspx?Symbol=IDR

http://www.eia.doe.gov

http://www.ifad.org/

http://socyberty.com/issues/is-opec-good-for-ghana/\#ixzz14fkyBRJ6

\section{Notes}

Note 1. There are at least 30 major multilateral, regional, or sub-regional development banks and funds. Of this number, about 10 are from the Middle East

Note 2. The "Dutch disease" describes a condition when a country's traditional industries are declining or internationally uncompetitive because the discovery of natural resources has created a prosperous new industry

Table 1. Dependence of OPEC countries on petroleum (own findings)

\begin{tabular}{|c|c|c|c|c|}
\hline & $\begin{array}{c}\text { GDP } \\
\text { millions \$ }\end{array}$ & $\begin{array}{c}\text { GDPper } \\
\text { capital \$ }\end{array}$ & $\begin{array}{c}\text { Dependence on petroleum } \\
\text { (petroleum export/GDP) } \%\end{array}$ & $\begin{array}{c}\text { Dependence on average } \\
1985-2005(\%)\end{array}$ \\
\hline Algeria & 56,221 & 1.766 & 29.3 & 17.0 \\
\hline Indonesia(former member) & 208,288 & 960 & 4,6 & 13,4 \\
\hline Iran & 134,738 & 2,010 & 19,4 & 23,7 \\
\hline Iraq & 19,854 & 789 & 37,9 & 39.3 \\
\hline Kuwait & 43,598 & 17,942 & 43,1 & 33,8 \\
\hline Libya & 23,001 & 4,064 & 59 & 36,4 \\
\hline Nigeria & 55,769 & 448 & 39,8 & 39,3 \\
\hline Qatar & 20,426 & 32,945 & 43,2 & 35.3 \\
\hline Saudi Arabia & 211,440 & 9,327 & 40,2 & 20.3 \\
\hline UAE & 75,640 & 24,244 & 33,3 & 21.0 \\
\hline Venezuela & 89,030 & 3,463 & 24,5 & 27.2 \\
\hline
\end{tabular}

Source: statistical agencies of each country and annual statistical reports of OPEC 
Table 2. Indonesian trade

\begin{tabular}{|c|c|c|c|}
\hline Trade us millions & 1988 & 1998 & 2008 \\
\hline Total export & 19.335 & 48.848 & 139.605 \\
\hline Fuel & 7.690 & 8.079 & 9.329 \\
\hline Estate crop & 2.070 & 3.974 & 18.467 \\
\hline Manufacture & 5.693 & 20.088 & 60.588 \\
\hline Total imports & 15.279 & 35.286 & 126.907 \\
\hline Food & 642 & 6.884 & 7.927 \\
\hline Energy and flue & 959 & 2.686 & 38.038 \\
\hline Capital goods & 5.096 & 9.932 & 42.397 \\
\hline
\end{tabular}

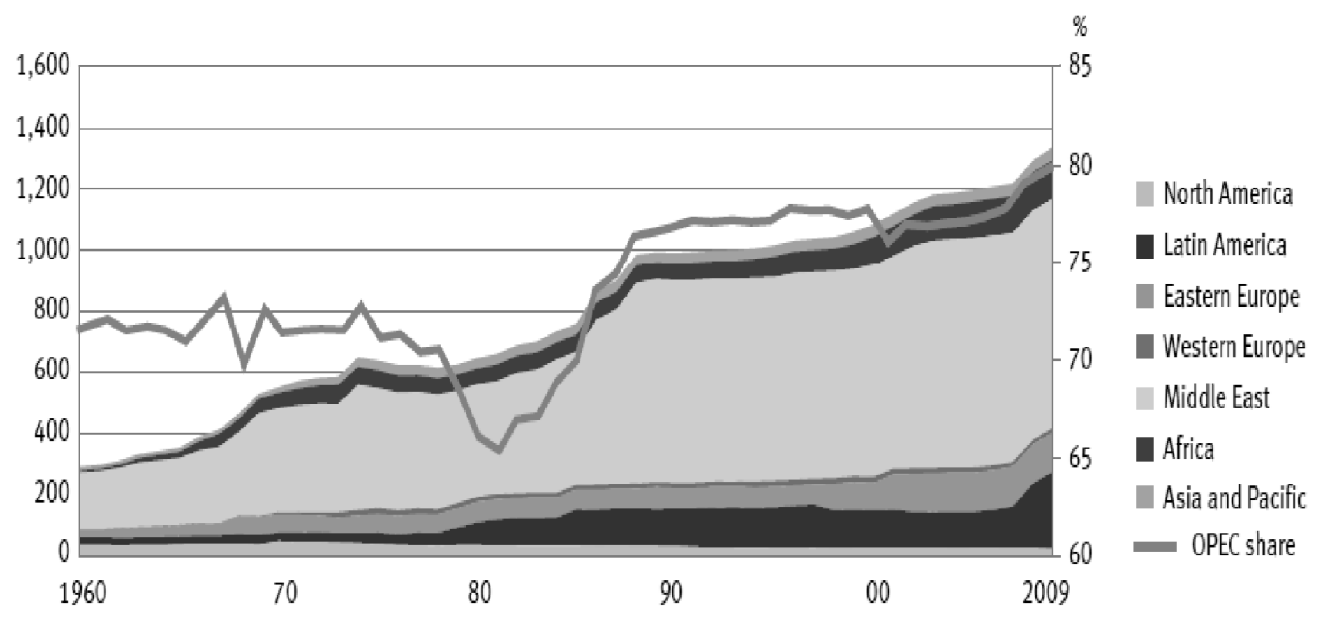

Figure 1. World proven crude oil reserve bn.b

Source: OPEC's annual reports

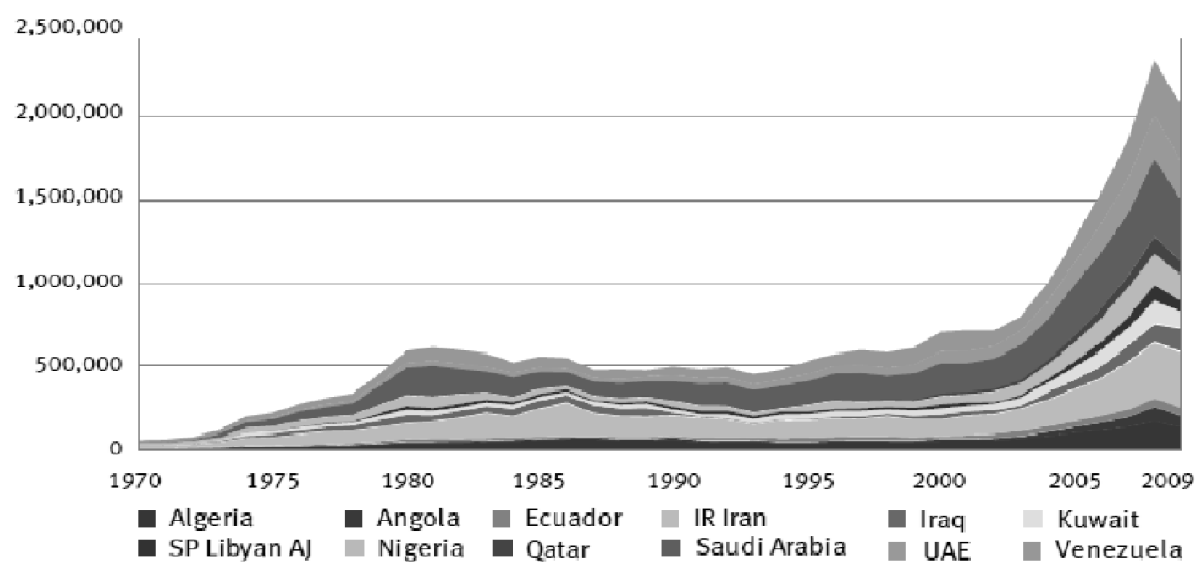

Figure 2 The GDP of OPEC member countries in US\$

Source: Source: OPEC's annual reports 


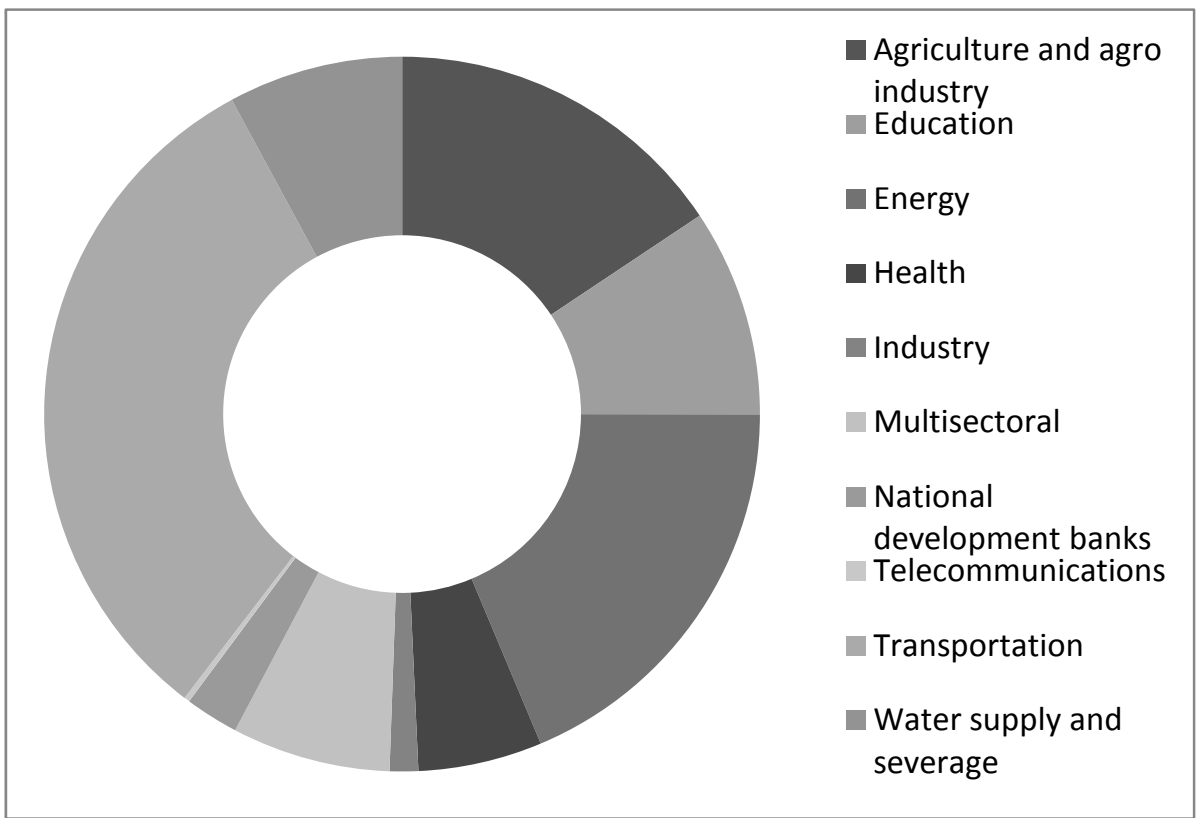

Figure 3 The distribution of public sector project loans as for December 2009 (million\$)

Source OFDI annual report 2009

\section{Appendix}

\begin{tabular}{|c|c|c|c|c|c|c|c|c|c|c|}
\hline & \multicolumn{2}{|c|}{2005} & \multicolumn{2}{|c|}{2006} & \multicolumn{2}{|c|}{2007} & \multicolumn{2}{|c|}{2008} & \multicolumn{2}{|c|}{2009} \\
\hline & $\begin{array}{c}\text { Net } \\
\text { export }\end{array}$ & $\begin{array}{c}\text { Petroleum } \\
\text { export }\end{array}$ & $\begin{array}{c}\text { Net } \\
\text { export }\end{array}$ & $\begin{array}{c}\text { Petroleum } \\
\text { export }\end{array}$ & $\begin{array}{c}\text { Net } \\
\text { export }\end{array}$ & $\begin{array}{c}\text { Petroleum } \\
\text { export }\end{array}$ & $\begin{array}{c}\text { Net } \\
\text { export }\end{array}$ & $\begin{array}{c}\begin{array}{c}\text { Petroleum } \\
\text { export }\end{array} \\
\end{array}$ & $\begin{array}{c}\text { Net } \\
\text { export }\end{array}$ & $\begin{array}{c}\text { Petroleum } \\
\text { export }\end{array}$ \\
\hline Algeria & 46,001 & 32,757 & 54,613 & 38,293 & 60,163 & 44,250 & 79,298 & 53,607 & 43,689 & 30,587 \\
\hline Angola & 24,105 & 22,101 & 31,862 & 29,131 & 44,396 & 42,132 & 72,179 & 69,364 & $40,, 985$ & 38,813 \\
\hline Ecuador & 10,100 & 5,870 & 12,778 & 7,545 & 13,852 & 8,329 & 18,511 & 11,673 & 13,797 & 6,965 \\
\hline IR Iran & 64,366 & 53,219 & 76,055 & 59,131 & 97,401 & 64,901 & 100,572 & 88,660 & 70,614 & 55,604 \\
\hline Iraq & 23,697 & 23,648 & 30,529 & 30,465 & 39,516 & 39,433 & 63,726 & 56,843 & 50,243 & 41,852 \\
\hline Kuwait & 44,868 & 42,440 & 56,025 & 53,188 & 62,483 & 59,001 & 87,011 & 82,682 & 50,243 & 46,569 \\
\hline $\begin{array}{c}\text { SP Libyan } \\
\text { AJ }\end{array}$ & 30,948 & 28,300 & 39,170 & 35,700 & 46,872 & 40,400 & 62,782 & 54,175 & 32,976 & 31,377 \\
\hline Nigeria & 52,402 & 49,722 & 62,772 & 54,604 & 59,907 & 51,170 & 87,459 & 74,033 & 33,439 & 31,377 \\
\hline Qatar & 25,339 & 17,585 & 34,051 & 23,350 & 41,490 & 29,130 & 54,912 & 54,175 & 33,356 & 26,840 \\
\hline $\begin{array}{c}\text { Saudi } \\
\text { Arabia } \\
\end{array}$ & 180,572 & 161,871 & 211,024 & 190,468 & 233,174 & 205,452 & 313,428 & 280,998 & 175,529 & 157,407 \\
\hline $\begin{array}{c}\text { United Arab } \\
\text { Emirates } \\
\end{array}$ & 117,287 & 55,079 & 145,586 & 70,100 & 178,613 & 73,816 & 239,213 & 102,073 & 174,725 & 58,656 \\
\hline Venezuela & 55,716 & 39,117 & 65,578 & 47,795 & 69,010 & 51,664 & 95,138 & 89,128 & 57,595 & 54,201 \\
\hline
\end{tabular}

Source: OPEC annual statistic bulletin 2009 p.p 14- 16 